\title{
ДУХОВНО-МОРАЛЬНЕ ВИХОВАННЯ ДІТЕЙ ДОШКІЛЬНОГО ВІКУ: ПРОБЛЕМИ І ПЕРСПЕКТИВИ
}

Наукова доповідь загальним зборам НАПН України 19 листопада 2021 р. https://doi.org/10.37472/2707-305X-2021-3-2-1-10

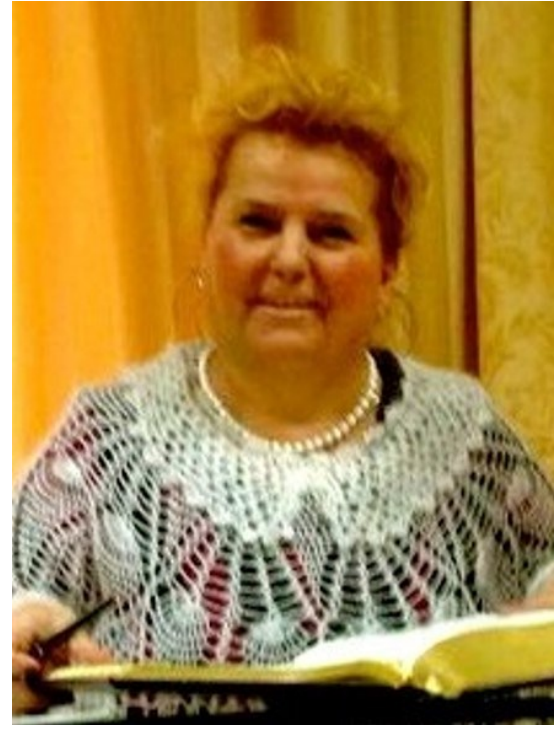

СІДАНІЧ Ірина Леонідівна доктор педагогічних наук, дочент, завідувач каферери педагогіки, адміністрування і спеціальної освіти Навчальнонаукового інституту менеджменту і психології Державного закладу вищої освіти "Університет менеджменту освіти», Національна академія педагогічних наук України, м. Київ, Україна

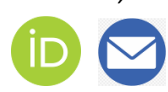

Анотачія. У доповіді проаналізовано проблеми і перспективи духовноморального виховання дітей дошкільного віку. Висвітлено результати роботи кафедри педагогіки, адміністрування і спеціальної освіти Навчально-наукового інституту менеджменту та психології ДзВО "Університет менеджменту освіти». Наведено ключові напрями професійної діяльності кафедри, які потребують посиленої уваги: розгортання науково-методичного забезпечення дошкільної освіти; підвищення якості професійної підготовки фахівия дошкільної освіти та надання освітніх послуг, які користуються попитом.

Ключові слова: дошкільна освіта; діти дошкільного віку; система ціннісних орієнтацій дитини; духовно-моральне виховання дітей; профресійно-педагогічна майстерність фахівия дошкільної освіти; париіальна програма.

У 2021 р. діяльність Навчально-наукового інституту менеджменту освіти та психології ДЗВО «Університет менеджменту освіти» здійснювалася відповідно до річного плану роботи Відділення вищої освіти та НАПН України з урахуванням завдань Стратегії розвитку Національної академії педагогічних наук України на 20162022 рр., положень Указу Президента України «Про Цілі сталого розвитку України на період до 2030 року» від 30 вересня 2019 р. № 722/2019, Програми спільної діяльності Міністерства освіти і науки України та Національної академії педагогічних наук України на 2017-2020 рр., Програми спільної діяльності Національної академії наук України та Національної академії педагогічних наук України на 2020-2022 рр. Інститут також координував науковоорганізаційну, науково-методичну, викладацьку діяльність кафедри педагогіки, адміністрування і спеціальної освіти, спрямовану на виконання плану роботи НАПН України на 2021 р.

Вітальною промовою президент Національної академії педагогічних наук України Василь Кремень 20 вересня 2021 р. на Форумі Всеукраїнського тижня дошкілля «Дошкільна освіта України 30» зазначив, що «щасливе життя наших прекрасних дітей залежатиме значною мірою від того, яке в них буде дошкілля. Бо саме в цьому віці закладаються риси людини і цінності, які вона сповідуватиме все життя». Доповідач підкреслив, що в українському суспільстві все більше цінується розвиток людини, розвиток дитини. «Розвиток людини, з одного боку, це показник прогресивності будь-якого суспільства, а з іншого - розвинена людина - основний важіль суспільного прогресу, особливо в час науково-інформаційних технологій» (Кремень, 2021). 
В. Кремень констатував, що «останнім часом зростає увага до освіти в державі, і дуже приємно, що зростає увага до дошкілля. Це рух суспільства у правильному напрямі. Але ще багато потрібно зробити, зокрема, добитися більшого усвідомлення суспільством значимості дошкілля у житті людини, значимості розвитку дитини в ранньому і дошкільному віці. Щасливе життя наших прекрасних дітей залежатиме значною мірою від того, яке в них буде дошкілля. Бо саме в цьому віці закладаються риси людини і цінності, які вона сповідуватиме все життя. Надзвичайно приємно, що в українському суспільстві все більше цінується розвиток людини, розвиток дитини» (Кремень, 2021).

Також В. Кремень зазначив: "Дошкілля тісно пов'язане із сім'єю. Тут багато залежить від педагогічної культури батьків, а я б сказав, що педагогізація суспільства, тобто надання знань і технологій батьківству, підготовка молодих людей до батьківства відіграє надзвичайно важливу роль. Безумовно, науково-методичне забезпечення дошкільної освіти. Зазначу, що багато зроблено вченими Національної академії педагогічних наук України. Але в Україні має бути єдиний досконалий центр розвитку дитини дошкільного віку» (Кремень, 2021).

Масштабність проведення, актуальність обговорених проблем, плідність наукових дискусій під час проведення Тижня дошкілля засвідчують, що сучасна дошкільна освіта $\epsilon$ у фокусі уваги як держави, науки, так і суспільства загалом. Захід став тією дискусійною платформою, яка об'єднала зусилля науковців, викладачів закладів вищої освіти й інститутів післядипломної педагогічної освіти, керівників і вихователів закладів дошкільної освіти всіх регіонів України, що спрямовані на осучаснення вітчизняної системи дошкільної освіти та забезпечення її якості.

Протягом останніх п'яти років кафедра педагогіки, адміністрування і спеціальної освіти Навчальнонаукового інституту менеджменту та психології ДЗВО «Університет менеджменту освіти» НАПН України спрямувала викладацьку, науковометодичну й організаційну діяльність на створення та забезпечення здорового, безпечного, комфортного середовища для всіх учасників освітнього процесу, підвищення якості освітньої діяльності та надання освітніх послуг, які користуються попитом.

Ці завдання залишаються пріоритетними і в новому навчальному році. Головне - досконало вивчити та оцінити якість освітньої діяльності й отримати інформацію про реальний стан справ у вищій освіті. Ця інформація дасть змогу побачити переваги й недоліки в організації освітнього процесу, підкаже можливі шляхи підвищення якості освітньої діяльності, відкриття нових спеціальностей.

Відповідно до Закону України «Про освіту», усім закладам освіти надано автономію у виборі основних пріоритетних напрямів та завдань в організації освітнього процесу із врахуванням детального та конструктивного аналізу результатів освітньої діяльності в минулому. Внутрішня система забезпечення якості освіти створюється не на папері, а в освітньому просторі, в управлінській та освітній діяльності. Забезпечення змісту вищої освіти реалізується згідно з Державним стандартом вищої освіти та освітньо-професійними чи освітньо-науковими програмами, навчально-методичними посібниками, затвердженими в установленому порядку Університетом менеджменту освіти НАПН України.

Міністерство освіти і науки України пропонувало для громадського обговорення проєкт Концепції розвитку дошкільної освіти, розробленої відповідно до законів України «Про освіту», «Про дошкільну освіту»; програми діяльності Кабінету Міністрів України, затвердженої постановою Кабінету Міністрів України від 2 квітня 2020 р. № 270; оперативного плану Міністерства освіти і науки України на 2020 рік, що затверджений наказом МОН України від 27 грудня 2019 р. № 1640; інших нормативно-правових актів. Кафедра активно підтримала ініціативи про підвищення якості професійної діяльності педагогічних кадрів та забезпечення безпечного освітнього середовища у закладах дошкільної освіти.

Міністерство освіти і науки України розробило проєкт Професійного стандарту «Вихователь закладу дошкільної освіти» та проєкт Професійного стандарту «Керівник (директор) закладу дошкільної освіти», які пройшли громадське обговорення, і у створенні яких співробітники кафедри, здобувачі вищої освіти і випускники магістри брали активну участь.

Вивчення та впровадження в практику роботи ЗДО нового державного Стандарту дошкільної освіти - Базового компонента дошкільної освіти сприяє якісній підготовці майбутнього фахівця освіти. В основу Стандарту дошкільної освіти (2020 р.) покладено ідеї гуманістичної педагогіки, духовно-морального, патріотичного і громадянського виховання та солідарної відповідальності 
держави, громади, родини, фахівців педагогічної освіти й інших професій, причетних до піклування, догляду та розвитку дітей дошкільного віку, і теорію природовідповідності. Базовий компонент, як Державний стандарт дошкільної освіти, реалізується освітніми програмами. Побудова освітнього процесу не за однією, а за кількома програмами дає змогу повніше врахувати інтереси, бажання, потреби, можливості й задатки кожного малюка задля своєчасного цілісного розвитку його особистості. Парціальні програми є додатковими і становлять основу для організації діяльності закладів дошкільної освіти за певним пріоритетним напрямом та надання дітям освітніх послуг через функціонування творчих студій чи гуртків. Освітні напрями визначають зміст роботи закладу дошкільної освіти через організацію педагогом базових (основних) видів діяльності, які збагачують досвід дитини та реалізуються як особистісне надбання дитини (результат розвитку) за підтримки батьків в умовах сімейного виховання. Педагогічні впливи забезпечують цілісність особистості, яка виявляється в розвинених емоціях, свідомості, що зростає, керованій поведінці.

Проблема науково-методичного забезпечення дошкільної освіти $є$ особливо актуальною із запровадженням різних форм ії здобуття. Тому на кафедрі разом з магістрами християнської педагогіки під науковим керівництвом академіка НАПН України А.М.Богуш розроблено зміст парціальної програми «Духовно-моральне виховання дітей дошкільного віку на християнських цінностях» та отримано гриф МОН України (Рекомендовано Міністерством освіти і науки України, протокол № 3 засідання комісії Науковометодичної ради з питань освіти МОН України від 18 листопада 2019 р.).

Метою навчальної програми «Духовноморальне виховання дітей дошкільного віку на християнських цінностях» $€$ ознайомлення 3 християнськими моральними цінностями, формування в дітей християнських моральних чеснот. У процесі досягнення мети передбачали реалізацію таких завдань:

- створення належних морально-етичних умов для самопізнання, самореалізації дітей дошкільного віку;

- ознайомлення дітей із основами християнської моралі як фундаменту загальнолюдських цінностей;
- ознайомлення дошкільників із християнськими моральними цінностями: істини, благочестя, добра, любові, краси, гідності, обов'язку, совісті, честі;

- формування свідомої та відповідальної особистості дитини на основі християнських духовних, моральних та культурних цінностей;

- збагачення словника дітей словами, пов'язаними із засадами духовно-морального виховання;

- залучення дітей до активної діяльності на основі духовно-моральних цінностей; забезпечення взаємозв'язку сім'ї і закладу дошкільної освіти в духовно-моральному вихованні дітей.

Для впровадження навчальної програми «Духовно-моральне виховання дітей дошкільного віку на християнських цінностях» у заклади дошкільної освіти кафедрі необхідно було підготувати відповідних фахівців. У зміст освітньо -професійної програми магістратури «Християнська педагогіка у вищій школі» введено навчальні дисципліни «Методика викладання предметів духовно-морального спрямування», «Основи християнської педагогіки», «Християнська етика і мораль», «Теорія християнського навчання і виховання» й інші спецкурси.

Ректорат Університету менеджменту освіти звернувся до директорів обласних департаментів освіти і науки України щодо програми духовноморального виховання дітей дошкільного віку на християнських цінностях: «3 огляду на те, що реалізація зазначеної програми сприятиме формуванню духовно-моральних цінностей особистості, оволодінню дітьми морально-етичними нормами поведінки, просимо сприяти впровадженню програми «Духовно-моральне виховання дітей дошкільного віку на християнських цінностях» (авторський колектив: А.М. Богуш, І.Л. Сіданіч, В.М. Жуковський, Т.В. Саннікова, В.Є. Сучок та інші) у закладах дошкільної освіти області.

Презентуємо результати розробленого, організованого і впровадженого кафедрою змісту, форм і методів духовно-морального виховання дітей дошкільного віку у практику дошкільної освіти за напрямами:

- науково-методична робота зі здобувачами вищої освіти за допомогою спланованих щороку конференцій, семінарів, круглих столів, вебінарів, участь у яких співвіднесено з академічними годинами підвищення кваліфікації педагогічних працівників. За останні роки працівники кафедри і випускники-магістри організували і провели низку заходів щодо підготовки фахівців до духовно-морального виховання дітей дошкільно- 
го віку, з-поміж яких практичні семінари, круглі столи, Всеукраїнський з'їзд педагогів з предметів духовно-морального спрямування, а також міжнародні тренінги «Уроки виховання характеру» на базі УМО для педагогів і керівників ДЗО (м. Київ, 2015-2020 рр.); виїзна Громадська рада 3 питань співпраці 3 церквами та релігійними організаціями при Міністерстві освіти і науки України з питань дошкільної освіти, УМО співорганізатор (Івано-Франківська обл., Косівський р-н, смт. Кути, 14 жовтня 2020 р.); відеоконференція ZOOM, до якої під'єдналися учасники з різних областей України про актуальність та особливості організації духовно-морального виховання дітей дошкільного віку у закладах дошкільної освіти України, пленарне засідання в форматі онлайнконференції у Южнінській міськраді (м. Южне, 4 серпня 2020 р.); Всеукраїнський семінар (в онлайн-форматі) «Реалізація парціальної програми «Духовно-моральне виховання дітей дошкільного віку на засадах християнських цінностей» (для педагогів закладів дошкільної освіти, консультантів ЦПРПП, обласних ІППО, відповідальних осіб органів управління ОТГ) організатори УМO, МОН України (https://bit.ly/3nhboZK 17-19 лютого 2021 р.), близько 8 тис. учасників семінару за три дні прослухали доповіді науковців, громадських діячів, методистів, управлінців, педагогів, фахівців дошкільної освіти;

- Il Всеукраїнська літня школа «Духовноморальне виховання дітей в закладах дошкільної освіти» УМО як курси підвищення кваліфікації на базі туристично-відпочинкового комплексу «Сяйво Карпат» (село Красноїлля Верховинського району Івано-Франківської області) за підтримки Міністерства освіти і науки України (29 червня - 4 липня 2021 р.) https://liveukraine.com.ua/2school ;

- Il всеукраїнський з'їзд педагогів з духовноморального виховання, де Університет менеджменту освіти був співорганізатором форуму (онлайн 5 травня 2021 р.);

- Всеукраїнський День дошкілля у Київському палаці дітей та юнацтва (2016-2020 рр.), зокрема, Всеукраїнський День Дошкілля в рамках педагогічного онлайн-марафону «Світ довкілля» вебінар «Духовно-моральне виховання дітей дошкільного віку на засадах християнських цінностей» (23 вересня 2020 р. на базі Університету менеджменту освіти НАПН України і КЗВО «Одеська академія неперервної освіти»).

Університет менеджменту освіти відповідно до листа МОН України від 23 квітня 2020 р. № 1/9-219

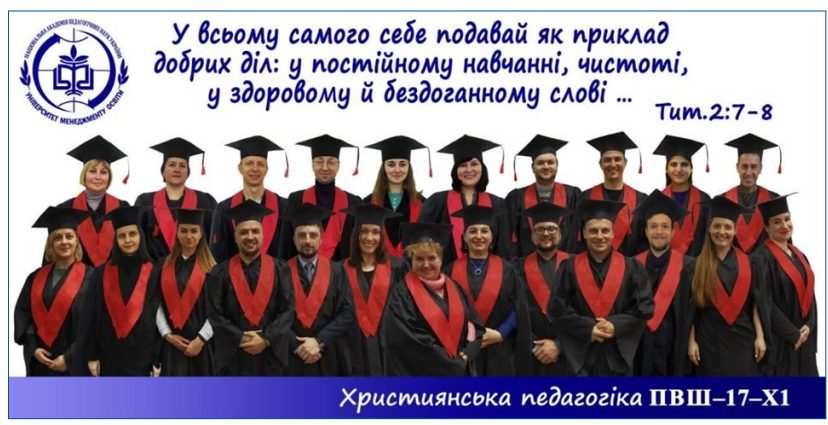

запланував в умовах запровадження посилених протиепідемічних заходів на територіях зі значним поширенням гострої респіраторної хвороби COVID-19 забезпечити права дітей на здобуття дошкільної освіти. У зв'язку з цим кафедра педагогіки, адміністрування і спеціальної освіти розробила цикл навчальних вебінарів 3 проблеми «Реалізація парціальної програми «Духовно-моральне виховання дітей дошкільного віку на засадах християнських цінностей в умовах пандемії», організатори МОН України, ДЗВО «Університет менеджменту освіти», ВБФ «Живи, Україно!», ІППО Чернівецької обл. (лист МOH України 22 січня 2021 р.). Духовноморальне виховання на християнських цінностях не суперечить світському, а органічно вплітається в нього, не порушуючи єдності й цілісності освітнього процесу, оскільки $€$ складником національного виховання. Необхідні нові підходи до формування морального буття молодого покоління, нові методи духовно-морального виховання $з$ урахуванням сучасних вимог. Плекати духовність у кожній дитині - святий обов'язок і справа честі фахівця дошкільної освіти. На основі такого підходу основна мета духовно-морального виховання полягає у тому, щоб сформувати високоморальну, добропорядну, чесну особистість. Душа дитини набагато раніше потребує уваги й турботи, ніж ії розум.

Отже, подальші перспективи досліджень у цьому напрямі можуть бути пов'язані з пошуком нових ефективних методів підтримки процесу духовного розвитку особистості. Особливості процесу підготовки майбутніх педагогів до духовно-морального виховання дітей полягають в осмисленні студентами необхідності свого особистісного удосконалення; розвитку комплексу професійних рис, якостей, здібностей; формуванні професійної компетенції і власного морального потенціалу; вивченні матеріалу змістового наповнення навчальних курсів для впровадження їх у власній професійній діяльності. Специфіка фахової підготовки майбутніх фахівців до духовно- 
морального виховання дітей дошкільного віку полягає в поступовому ускладненні змісту і безперервності процесу загалом. Сучасний фахівець дошкільної освіти має сам нести мораль і духовність у суспільство, прищеплювати дітям моральність як базову якість особистості, бути для них взірцем для наслідування та допомагати родині у здійсненні процесу духовно-морального зростання дітей.

Проблема формування морально-духовної розвиненої культурної особистості фахівця $\epsilon$ інноваційною педагогічною цінністю для сучасної системи вищої освіти. Готовність майбутнього фахівця дошкільної освіти до духовно-морального виховання дітей визначає єдність особистісної та професійної (теоретичної, практичної і наукової) підготовки, тобто має інтеграційний характер. Особливість педагогічної діяльності, спрямованої на духовно-моральне виховання дітей дошкільного віку, полягає в прямій залежності від вибору напрямів, засобів і методів психолого-педагогічного впливу, від ціннісних орієнтацій фахівця.

Психолого-педагогічна підготовка майбутніх фахівців до здійснення духовно-морального виховання дітей має пряму залежність від поставлених завдань, які зумовлені соціальними запитами та потребами практики. Ця наукова розвідка не $€$ завершеною, оскільки з'ясовано й доведено необхідність у створенні бази даних щодо кількості закладів дошкільної освіти, які працюють за парціальною програмою «Духовно-моральне виховання дітей дошкільного віку на християнських цінностях», визначеності закладів вищої освіти, які здійснюють підготовку фахівців до духовно-морального виховання дітей дошкільного віку. Оновлений зміст дошкільної освіти, програми та навчально-методичне забезпечення, що його реалізують, спонукають до оновлення способів підготовки майбутніх фахівців: апробація вітчизняних і світових освітніх інновацій; апробація інновацій, розроблених у ході експериментальної роботи регіонального рівня; розроблення й експериментальна перевірка продуктивності застосування освітніх і педагогічних інновацій тощо.

\section{СПИСОК ВИКОРИСТАНИХ ДЖЕРЕЛ}

Закон України «Про дошкільну освіту». (2001, 11 липня). https://zakon.rada.gov.ua/laws/show/2628-14

Кевішас, Й., \& Отич, О.М. (Уклад.). (2019). Горизонт духовності виховання / The Horizon of Spirituality of Education : колективна монографія. Вільнюс: Zuvedra. https://lib.iitta.gov.ua/719526/

Кремень, В.Г. (2021). Форум Всеукраїнського тижня дошкілля «Дошкільна освіта України 30». Вітальна промова президента НАПН України, 20 вересня 2021р., м. Київ, Україна. Вісник Начіональної академії педагогічних наук України, 3(2). https:// doi.org/10.37472/2707-305X-2021-3-2-16-1

Міністерство освіти і науки України. (2021). Всеукраїнський тиждень дошкілля "Дошкільна освіта України 30»-2021. https://bit.ly/3qAg7rO

Міністерство освіти і науки України. (2021, 12 січня). Про затвердження Базового компонента дошкільної освіти (Державного стандарту дошкільної освіти) нова редакція (33). https:// bit.ly/39UTWUn

Міністерство освіти і науки України. (2021, 20 вересня). Сергій Шкарлет розповів про стратегічні чілі державної політики у сорері дошкільної освіти. https://cutt.ly/REcti5v

Міністерство освіти і науки України. (2021, 20 вересня). Форум Всеукраїнського тижня дошкілля «Дошкільна освіта України 30» [Відео]. Facebook. https://bit.ly/3rlrvqp

Національна академія педагогічних наук України. (2021, 20 вересня). Василь Кремень: «Щасливе життя наших прекрасних дітей залежатиме в значній мірі від того, яке в них буде дошкілля». http://naps.gov.ua/ua/press/releases/2423/

\section{SPIRITUAL AND MORAL EDUCATION OF PRESCHOOL CHILDREN: PROBLEMS AND PROSPECTS Scientific Report to the General Meeting of the National Academy of Educational Sciences of Ukraine, November 19, 2021}

Iryna Sidanych

DSc in Pedagogy, Associate Professor, Head of the Department of Pedagogy, Administration and Special Education of the Educational and Scientific Institute of Management and Psychology, State Higher Education Institution

"University of Educational Management", National Academy of Educational Sciences of Ukraine, Kyiv, Ukraine

Abstract. The report analyses the problems and prospects of spiritual and moral education of preschool children. The Department of Pedagogy, Administration and Special Education of the Educational and Scientific Institute of Management and Psychology at the SHEI "University of Educational Management" activities results were highlighted. The key directions of professional activity of the department are given, which require increased attention: promotion of scientific and methodical support of preschool education; improvement of quality of preschool educators' professional training and provision of educational services, which are in demand.

Keywords: preschool education; preschool age children; system of valuable orientation of the child; spiritual and moral education of children; professional and pedagogical mastery of preschool educator; partial programme.

Дата публікації: 30 грудня 2021 р. 